\title{
1
}

\section{CAPSTONE PROJECTS, PROFESSIONAL COMPETENCIES, AND ETHICAL APPLIED RESEARCH}

This chapter discusses capstone research projects' purposes, the Council on Social Work Education (CSWE, 2015) professional competencies, the National Association of Social Workers (NASW, 2017) Code of Ethics, ethical research principles and standards, institutional review boards, informed consent, and different types of applied research.

By the end of the chapter, you will be able to do the following:

- Describe the purpose of capstone projects and learning pathways.

- List nine professional social work competencies.

- Describe the concept of holistic competency.

- Describe the NASW Research and Evaluation ethical standards.

- Determine if a research project requires Institutional Review Board (IRB) approval.

- Create an informed consent form.

- Describe five approaches to applied social work research.

\section{Capstone Projects}

A capstone project is a multifaceted assignment that serves as a culminating academic and intellectual experience for students (The Glossary of Educational Reform, 2016). Capstone projects in social work are typically designed to foster critical thinking and to develop written and oral communication skills as well as research skills. They are also used as a vehicle for Bachelor of Social Work (BSW) and Master of Social Work (MSW) students to demonstrate mastery of the professional social work competencies. Capstone projects tied to students' field placements can also be used to foster organizational and/or community change to promote social justice and improved social work services.

Capstone projects are often viewed as learning pathways that expand the educational experience beyond the courses offered (The Glossary of Educational Reform, 2013). They allow students to apply the knowledge acquired in individual courses 
to research projects that help create integrated learning experiences that go beyond individual courses. Capstone projects are also learning pathways to students' ongoing development as professional social workers. They help students see the interconnections among the professional competencies and to view social work practice from a holistic perspective.

Capstone projects are similar in some ways to standard research papers but in many ways very different. A standard research paper has a particular format that sequentially describes each component of a research project. Capstone projects in social work have a different format. They are designed to cover a number of discreet topics such as the research process, policy issues and recommendations, social problem analysis, as well as coverage of a range of social work competencies. The end products of capstone projects typically include a written report as well as an oral component with some type of electronic visual presentation, such as PowerPoint, Keynote, or Prezi.

\section{Professional Social Work Competencies}

For social work education programs in the United States, the accrediting body is the CSWE Commission on Accreditation (COA). The CSWE's Commission on Educational Policy (COEP) creates educational policy for social work education and the COA creates accreditation standards. The educational policy and accreditation standards together form the Educational Policy and Accreditation Standards (EPAS) that guide the accreditation of baccalaureate- and master-level social work educational programs (Poulin \& Matis, 2015).

\section{ACCREDITATION AND SOCIAL WORK COMPETENCIES: EPAS 2015}

Each of the nine professional competencies describes the knowledge, values, skills, and cognitive and affective processes that make up the competency at the generalist level of practice, followed by a set of behaviors that integrate these components. These behaviors represent examples of observable components of the competencies, while the preceding statements represent the underlying content and processes that inform the behaviors (CSWE, 2015).

\section{Competency 1: Demonstrate Ethical and Professional Behavior}

Social workers understand the value base of the profession and its ethical standards, as well as relevant laws and regulations that may impact practice at the micro, mezzo, and macro levels. Social workers understand frameworks of ethical decision-making and how to apply principles of critical thinking to those frameworks in practice, research, and policy arenas. Social workers recognize personal values and the distinction between personal and professional values. They also understand how their personal experiences and affective reactions influence their professional judgment and behavior. Social workers understand the profession's history, its mission, and the roles and responsibilities of the profession. Social workers also understand the role of other professions when engaged 
in interprofessional teams. Social workers recognize the importance of lifelong learning and are committed to continually updating their skills to ensure they are relevant and effective. Social workers also understand emerging forms of technology and the ethical use of technology in social work practice. Social workers:

- make ethical decisions by applying the standards of the NASW Code of Ethics, relevant laws and regulations, models for ethical decision-making, ethical conduct of research, and additional codes of ethics as appropriate to context;

- use refection and self-regulation to manage personal values and maintain professionalism in practice situations;

- demonstrate professional demeanor in behavior; appearance; and oral, written, and electronic communication;

- use technology ethically and appropriately to facilitate practice outcomes; and

- use supervision and consultation to guide professional judgment and behavior.

\section{Competency 2: Engage Diversity and Difference in Practice}

Social workers understand how diversity and difference characterize and shape the human experience and are critical to the formation of identity. The dimensions of diversity are understood as the intersectionality of multiple factors including but not limited to age, class, color, culture, disability and ability, ethnicity, gender, gender identity and expression, immigration status, marital status, political ideology, race, religion/spirituality, sex, sexual orientation, and tribal sovereign status. Social workers understand that, as a consequence of difference, a person's life experiences may include oppression, poverty, marginalization, and alienation as well as privilege, power, and acclaim. Social workers also understand the forms and mechanisms of oppression and discrimination and recognize the extent to which a culture's structures and values, including social, economic, political, and cultural exclusions, may oppress, marginalize, alienate, or create privilege and power. Social workers:

- apply and communicate understanding of the importance of diversity and difference in shaping life experiences in practice at the micro, mezzo, and macro levels;

- present themselves as learners and engage clients and constituencies as experts of their own experiences; and

- apply self-awareness and self-regulation to manage the influence of personal biases and values in working with diverse clients and constituencies.

\section{Competency 3: Advance Human Rights and Social, Economic, and Environmental Justice}

Social workers understand that every person regardless of position in society has fundamental human rights such as freedom, safety, privacy, an adequate standard of living, healthcare, and education. Social workers understand the global interconnections of oppression and human rights violations and are knowledgeable about theories of human need and social justice and strategies to promote social and economic justice and human 
rights. Social workers understand strategies designed to eliminate oppressive structural barriers to ensure that social goods, rights, and responsibilities are distributed equitably, and that civil, political, environmental, economic, social, and cultural human rights are protected. Social workers:

- apply their understanding of social, economic, and environmental justice to advocate for human rights at the individual and system levels; and

- engage in practices that advance social, economic, and environmental justice.

\section{Competency 4: Engage in Practice-Informed Research and Research-Informed Practice}

Social workers understand quantitative and qualitative research methods and their respective roles in advancing a science of social work and in evaluating their practice. Social workers know the principles of logic, scientific inquiry, and culturally informed and ethical approaches to building knowledge. Social workers understand that evidence that informs practice derives from multidisciplinary sources and multiple ways of knowing. They also understand the processes for translating research findings into effective practice. Social workers:

- use practice experience and theory to inform scientific inquiry and research;

- apply critical thinking to engage in analysis of quantitative and qualitative research methods and research findings; and

- use and translate research evidence to inform and improve practice, policy, and service delivery.

\section{Competency 5: Engage in Policy Practice}

Social workers understand that human rights and social justice, as well as social welfare and services, are mediated by policy and its implementation at the federal, state, and local levels. Social workers understand the history and current structures of social policies and services, the role of policy in service delivery, and the role of practice in policy development. Social workers understand their role in policy development and implementation within their practice settings at the micro, mezzo, and macro levels and they actively engage in policy practice to effect change within those settings. Social workers recognize and understand the historical, social, cultural, economic, organizational, environmental, and global influences that affect social policy. They are also knowledgeable about policy formulation, analysis, implementation, and evaluation. Social workers:

- identify social policy at the local, state, and federal levels that impacts well-being, service delivery, and access to social services;

- assess how social welfare and economic policies impact the delivery of and access to social services; and

apply critical thinking to analyze, formulate, and advocate for policies that advance human rights and social, economic, and environmental justice. 


\section{Competency 6: Engage With Individuals, Families, Groups, Organizations, and Communities}

Social workers understand that engagement is an ongoing component of the dynamic and interactive process of social work practice with, and on behalf of, diverse individuals, families, groups, organizations, and communities. Social workers value the importance of human relationships. Social workers understand theories of human behavior and the social environment, and critically evaluate and apply this knowledge to facilitate engagement with clients and constituencies, including individuals, families, groups, organizations, and communities. Social workers understand strategies to engage diverse clients and constituencies to advance practice effectiveness. Social workers understand how their personal experiences and affective reactions may impact their ability to effectively engage with diverse clients and constituencies. Social workers value principles of relationship-building and interprofessional collaboration to facilitate engagement with clients, constituencies, and other professionals as appropriate. Social workers:

- apply knowledge of human behavior and the social environment, person-inenvironment, and other multidisciplinary theoretical frameworks to engage with clients and constituencies; and

- use empathy, reflection, and interpersonal skills to effectively engage diverse clients and constituencies.

\section{Competency 7: Assess Individuals, Families, Groups, Organizations, and Communities}

Social workers understand that assessment is an ongoing component of the dynamic and interactive process of social work practice with, and on behalf of, diverse individuals, families, groups, organizations, and communities. Social workers understand theories of human behavior and the social environment, and critically evaluate and apply this knowledge in the assessment of diverse clients and constituencies, including individuals, families, groups, organizations, and communities. Social workers understand methods of assessment with diverse clients and constituencies to advance practice effectiveness. Social workers recognize the implications of the larger practice context in the assessment process and value the importance of interprofessional collaboration in this process. Social workers understand how their personal experiences and affective reactions may affect their assessment and decision-making. Social workers:

- collect and organize data, and apply critical thinking to interpret information from clients and constituencies;

- apply knowledge of human behavior and the social environment, personin-environment, and other multidisciplinary theoretical frameworks in the analysis of assessment data from clients and constituencies;

- develop mutually agreed-on intervention goals and objectives based on the critical assessment of strengths, needs, and challenges within clients and constituencies; and

- select appropriate intervention strategies based on the assessment, research knowledge, and values and preferences of clients and constituencies. 


\section{Competency 8: Intervene With Individuals, Families, Groups, Organizations, and Communities}

Social workers understand that intervention is an ongoing component of the dynamic and interactive process of social work practice with, and on behalf of, diverse individuals, families, groups, organizations, and communities. Social workers are knowledgeable about evidence-informed interventions to achieve the goals of clients and constituencies, including individuals, families, groups, organizations, and communities. Social workers understand theories of human behavior and the social environment, and critically evaluate and apply this knowledge to effectively intervene with clients and constituencies. Social workers understand methods of identifying, analyzing, and implementing evidence-informed interventions to achieve client and constituency goals. Social workers value the importance of interprofessional teamwork and communication in interventions, recognizing that beneficial outcomes may require interdisciplinary, interprofessional, and interorganizational collaboration. Social workers:

- critically choose and implement interventions to achieve practice goals and enhance capacities of clients and constituencies;

- apply knowledge of human behavior and the social environment, person-inenvironment, and other multidisciplinary theoretical frameworks in interventions with clients and constituencies;

- use interprofessional collaboration as appropriate to achieve beneficial practice outcomes;

- negotiate, mediate, and advocate with and on behalf of diverse clients and constituencies; and

- facilitate effective transitions and endings that advance mutually agreed-on goals.

\section{Competency 9: Evaluate Practice With Individuals, Families, Groups, Organizations, and Communities}

Social workers understand that evaluation is an ongoing component of the dynamic and interactive process of social work practice with, and on behalf of, diverse individuals, families, groups, organizations, and communities. Social workers recognize the importance of evaluating processes and outcomes to advance practice, policy, and service-delivery effectiveness. Social workers understand theories of human behavior and

\section{Reflection Questions}

1. In which competency do you feel you have progressed the most in terms of your professional development? Why?

2. In which competency do you feel least confident in terms of your professional development? Why? How might you strengthen your knowledge about the substantive content of the competency and your skills in implementing the competency? the social environment, and critically evaluate and apply this knowledge in evaluating outcomes. Social workers understand qualitative and quantitative methods for evaluating outcomes and practice effectiveness. Social workers:

- select and use appropriate methods for evaluation of outcomes;

- apply knowledge of human behavior and the social 
environment, person-in-environment, and other multidisciplinary theoretical frameworks in the evaluation of outcomes;

- critically analyze, monitor, and evaluate intervention and program processes and outcomes; and

apply evaluation findings to improve practice effectiveness at the micro, mezzo, and macro levels (CSWE, 2015).

\section{Holistic Competency}

McKnight (2013) proposes that competence is an "ongoing ability" to "integrate knowledge, skills, judgment, and professional attributes in order to practice safely and ethically" within one's professional scope (p. 460). The CSWE defines holistic competence as the demonstration of knowledge, values, skills, and cognitive and affective processes that include the social worker's critical thinking, affective reactions, and exercise of judgment in regard to unique practice situations (CSWE, 2015, p. 6).

\section{KNOWLEDGE}

The knowledge dimension is your mastery of the substantive content of the competency. Social work curricula are constructed to provide students with course work that provides readings, assignments, and discussions that educate students on the current knowledge related to each competency. Students also increase their competency knowledge through their own research on the topics that compose the underlying content and processes of each competency. A prerequisite of one ability to demonstrate competence is a solid understanding and knowledge of the literature that makes up the competency (Poulin \& Matis, 2020).

\section{VALUES}

The values dimension is less clear than the knowledge dimension. Although competency $\# 1$ is about values and professional behavior, the other eight competencies all have social work values dimensions as well. The values dimensions can have knowledge (social work values) as well as skill (ethical behavior and decision-making) components. Understanding the values and ethics associated with the application of the different social work competencies in unique practice situations is a fundamental aspect of ethical decision-making and professional social work competence (Poulin \& Matis, 2020).

\section{SKILLS}

The skills dimension refers to your ability to apply social work knowledge and values in your social work practice. There are numerous skills associated with each professional competency. Your field placement experience provides you with an opportunity to apply, refine, and learn social work skills in practice situations. Your skill is your ability to apply social work theories, concepts, and techniques in your practice with clients and/or constituents (Poulin \& Matis, 2020). 


\section{COGNITIVE AND AFFECTIVE PROCESSES}

This dimension has three associated subdimensions-critical thinking, affective reactions, and professional judgment. Critical thinking is the open-minded search for understanding. It is a process focused on explaining the "why." The process includes "providing evidence, examining the implications of the evidence, recognizing any potential contradictions and examining alternative explanations" (Heron, 2006, p. 221). The CSWE (2015) defines critical thinking as "an intellectual, disciplined process of conceptualizing, analyzing, evaluating, and synthesizing multiple sources of information generated by observation, reaction, and reasoning" (p. 20). Critical thinking is a crucial component of professional competence because it ensures that your social work practice is reasoned and thoughtful and not the rote application of social work techniques.

Affective reaction, on the other hand, generally refers to the affective component of social work practice with clients (Rubaltelli \& Slovic, 2008). It is the worker's emotional response to the client's presentation and situation. It is tied to empathy and other affective processes. Affective reaction has relevance for social work competency in that effective social work practice requires affective understanding of the client as well as one's own feelings, emotions, and reactions (Poulin \& Matis, 2015).

Professional judgment is about decision-making in social work practice. A key issue debated in relation to decision-making in social work is the extent to which social workers use analytical versus intuitive reasoning styles (Collins \& Daly, 2011). Thus, professional judgment is reasoned decision-making based on evidence, knowledge, analytical reason-

\section{Reflection Questions}

1. How could you assess the cognitive and affective reactions dimensions of a competency related to designing and implementing a capstone research project?

2. What affective reactions do you anticipate in conducting your capstone research project? How will you manage your affective reactions? ing, and practice wisdom. It is a process of examining all facets of the case and making a reasoned decision supported by both objective and subjective evidence. Exercising informed professional judgment is a critical component of professional social work competence (Poulin \& Matis, 2015).

\section{Competency Model of Social Work Practice}

The nine social work competencies and the associated dimensions are the interrelated components of professional social work practice. The competencies are interconnected. They do not stand alone. Holistic competency is the practice of social work utilizing multiple professional competencies in each practice activity or client interaction. Figure 1.1 shows a conceptualization of the interrelationships among the nine professional social work competencies. The competencies with the two outer bands are those that apply broadly to all practice situations. The ethical and professional behavior, diversity and difference, and social, economic, and environmental justice competencies are fundamental components of effective social work practice at all levels (Poulin \& Matis, 2020).

The competencies in the middle band of the figure are the two areas of social work practice that are not client based-policy practice and research. These competencies are 
Ethics and Professional Behavior

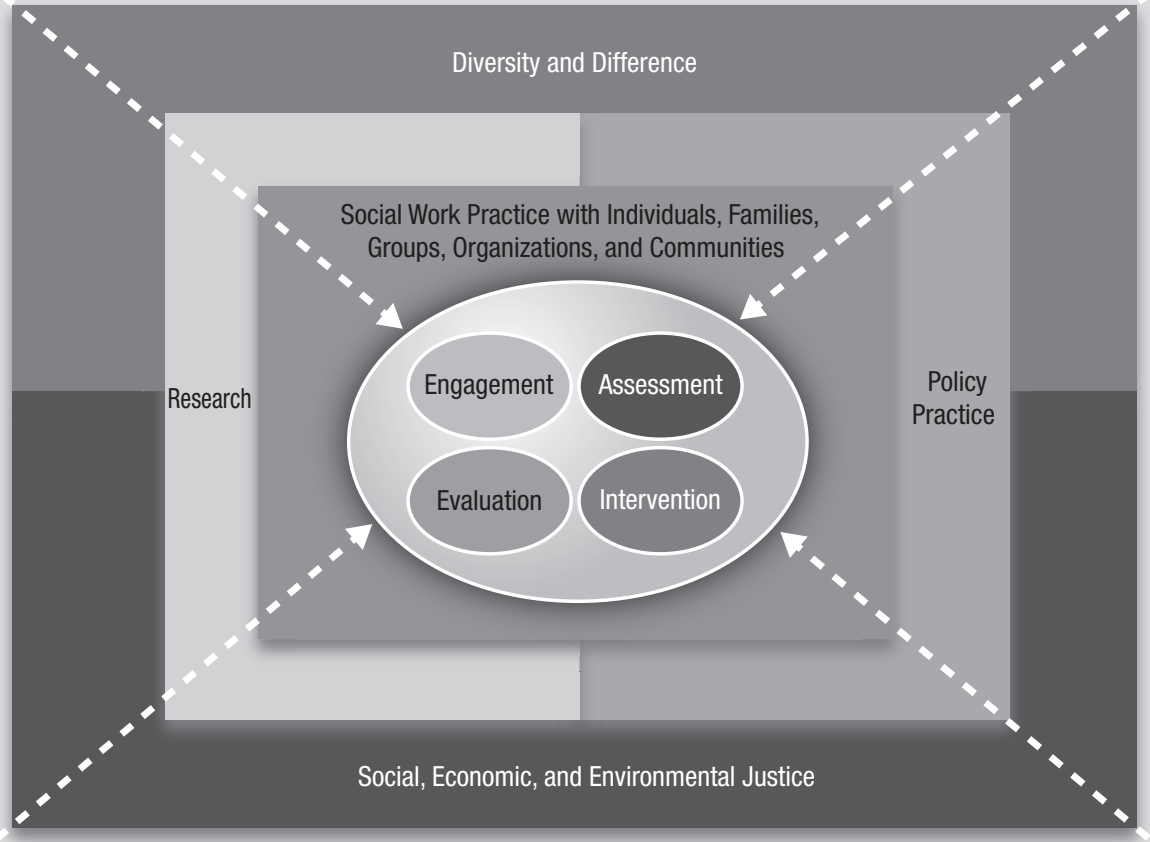

FIGURE 1.1 Interrelationships of social work competencies.

informed by the ethical behavior, diversity, and justice competencies and in turn inform social work practice with client and constituency competencies. The center component represents the engagement, assessment, intervention, and evaluation competencies in social practice with individuals, families, groups, organizations, and communities. Thus, the ethical behavior, diversity, social justice, policy practice, and research competencies all inform the practice competencies of engagement, assessment, intervention, and evaluation with individuals, families, groups, organizations, and communities (Poulin \& Matis, 2015).

Thus, the nine professional competencies are interconnected in the delivery of social work practice with clients and constituencies. For example, a social worker's ability to engage with an individual client is influenced by their ethical and professional behavioral competency; diversity and difference competency; social, economic, and environmental justice competency; and possibly their policy practice and research competencies. In short, most social work practice situations require the use of all or most of the nine professional competencies. Thus, to be a competent social work practitioner you must develop knowledge, values, skill, cognitive process, and affective processes competency for each professional competency and be able to apply multiple competencies in a variety of practice situations (Poulin \& Matis, 2020). 


\section{Social Work Values and Ethics}

The practice of social work is based on a number of value positions and principles that guide the work with clients irrespective of the approach used, the presenting client problem, the client population, or the setting in which services are provided. These values and principles apply to all forms of social work practice including policy and research practice (Poulin et al., 2019).

\section{CORE SOCIAL WORK VALUES}

\section{Reflection Questions}

1. How are your personal values and professional social work values similar? How do they differ?

2. How do you manage and regulate any differences between your personal values and the professional values of social work?
Social work is a value-based profession (Reamer, 2013). Values provide the basis for professional social work practice (Congress \& McAuliffe, 2006; Gumpert \& Black, 2006). They guide the actions we take and our evaluations of what is "good" (DuBois \& Miley, 2014). Social

work has a rich tradition of principles and beliefs.

The heart of these is reflected in the NASW Code of Ethics (NASW, 2017) that identifies core social work values, which are referred to as "ethical principles." The core professional values are: service to others; social justice; dignity and worth of the person; and importance of human relationships, integrity, and competence. These values and their associated ethical standards all play a critical role in social work practice. The NASW Code of Ethics is available online at https://www.socialworkers.org/About/Ethics /Code-of-Ethics/Code-of-Ethics-English

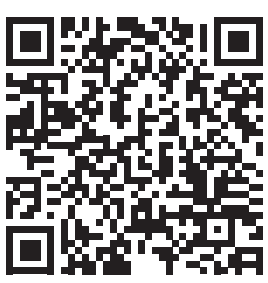

\section{Ethical Standards}

The core social work values and ethical principles embody the ideals to which all social workers should aspire. The Code of Ethics sets specific standards and explains how the core values and principles influence the actions of professional social workers. The standards spell out social workers' ethical responsibilities to clients, to colleagues, in practice settings, as professionals, to the social work profession, and to the broader society (NASW, 2017). They are detailed, comprehensive guidelines for professional behavior. The NASW Code of Ethics (NASW, 2017) identifies the six areas of professional behavior: responsibilities to clients, to colleagues, to practice settings, and as professionals, to the profession, and to the broader society. Each area of responsibility includes a number of subareas. It is important that you carefully review the detailed descriptions of the standards found in the NASW Code of Ethics available online at https://www.socialworkers .org/About/Ethics/Code-of-Ethics/Code-of-Ethics-English

The NASW Ethical Standards cover a very broad range of behaviors from interactions with clients to participation in larger societal change. Thus, as a social worker it is your ethical responsibility to have these standards of behavior guide your professional 
behavior in all aspects of your professional life. Without a doubt, doing so will create challenges when different ethical standards are in conflict in your practice with clients, experiences with colleagues, and at your agency or field placement. The ethical standards related to being a professional, the social work profession, and society are more under your own control and the choices you make. Nevertheless, conflicts are possible among and between the areas of professional responsibilities (Poulin \& Matis, 2020).

The NASW Code of Ethics (2017) standard on Evaluation and Research has 17 subsections related to applied research on evaluating organizational and community interventions and outcomes. The Code of Ethics subsections address social workers' ethical responsibilities to do the following:

- Evaluate the programs and practice interventions.

- Promote and facilitate evaluation of programs and services.

- Develop guidelines for protecting evaluation participants.

- Obtain voluntary and informed consent.

- Provide participants the right to withdraw from the evaluation.

- Ensure access to supportive services.

- Protect participants from harm.

- Ensure confidentiality.

- Report finding accurately.

- Avoid conflicts of interest.

- Use responsible research practices.

In sum, social workers have an ethical responsibility to evaluate program implementation and outcomes using appropriate research practices that protect human subjects. Social workers also have an ethical responsibility to avoid conflicts of interest in conducting evaluation of social work programs and interventions and to disseminate accurate evaluation findings.

\section{Institutional Review Boards}

An IRB is a committee that reviews the methods proposed for research to ensure that they are ethical. Federal regulations require that research projects involving human participants be approved or be determined exempt prior to the start of the research (U.S. Food and Drug Administration, 2019). The main goal of IRBs is the protection of human subjects. Most colleges, universities, and medical facilities have IRBs and require proposed research projects conducted by persons affiliated with their institution be reviewed and approved by the IRB. The purpose of the review is to ensure that appropriate steps are taken to protect the rights and welfare of humans participating as subjects in a research study. The review assesses the ethics of the research to ensure the protection of the human participants in the study.

The Belmont Report, published in 1979 by the National Commission for the Protection of Human Subjects of Biomedical and Behavioral Research, provides the ethical foundation for the federal regulations for the protection of human research subjects. The 
major ethical principles guiding the protection of human subjects are respect for persons, beneficence, and justice. As described in the Belmont Report, respect for persons includes participants' rights to make decisions for themselves. This requires that human subjects must freely provide informed consent to participate in the research study. Participation in the research is acknowledged as voluntary and is free from cohesion or undue influence by the researcher. The principle of beneficence refers to maximize possible benefits of the study and minimize potential risks. The risks to study participants must be reasonable compared to the potential to subjects and/or society. The principle of justice refers to an equal distribution of benefits among the research subjects. All IRBs use the ethical principles outlined in the Belmont Report in their assessment and review of research studies.

\section{DETERMINING IF YOUR PROJECT REQUIRES IRB APPROVAL}

There are three types of IRB reviews. A full board review is used when there is potential serious harm or the subject population is considered vulnerable. An expedited review is done when there is minimal risk for the study participants. Expedited reviews are usually done by two or three IRB members with approval by the full committee. The third type of review is exempt. The IRB does not approve an exempt application; they just determine if the project should be exempt. Before beginning your proposed capstone research project, you should first determine if your project requires IRB approval or an exempt review.

The federal regulation [45 CFR 46.102(1)] specifies that IRB review and approval is required for projects that meet the definition of research, involve human subjects, and involve an interaction or intervention with human subjects (Department of Health and Human Services, 2016). Research is defined as a systematic investigation designed to develop or contribute to generalized knowledge. "Contribute to generalizable knowledge means that the purpose or intent of the project is to test or to develop scientific theories or hypotheses, or to draw conclusions that are intended to be applicable and/or shared beyond the populations or situations being studied" (Boston University, 2020, para. 5). If your applied research project does not meet the federal government's definition of research then IRB approval is not required. However, most IRBs require an exempt review in which the IRB determines if your project has met the federal definition for being exempt.

Research projects that do not require IRB approval include data collected for administrative purposes, program evaluations, quality assurance and quality improvement projects, and single case studies. Also, course projects are often exempt from IRB approval. Most applied research projects as well as course projects do not meet the knowledge generalization criteria of the federal definition of research. However, we recommend that you check with your course professor and your university IRB about whether or not an exempt IRB application is required. Regardless, it is imperative that you protect any human subjects involved in your research and that you follow the research and evaluation ethical standards.

\section{INFORMED CONSENT}

If you are planning on using human subjects in your capstone research project, then you will need to obtain informed consent from your participants. All of your study participants will have to voluntarily agree to participate in your research. To do so they will 
need to understand the purpose of the research, the potential risks and benefits, and what will be expected. Your research participants will need to read or have read to them an informed consent form and indicate that they voluntarily agree to participate. The informed consent form should be written in a language and at a reading level appropriate to the subject population. Even for college-educated participants the language should be keep as simple and jargon free as possible. It should also be written from the prospective of the participant, that is, "I volunteer to participate."

The following information should be included on your consent form:

- That you are a student researcher

- The name of your faculty advisor

- The activities involving research

- The purposes of the research

- The procedures to be performed

- Participation is voluntary

- The time involved for study participation

- How confidentiality of data is maintained

- Risks of participating in the study

- Benefits of participating in the study (if any)

- Name and contact information for the investigator (Boston University, n.d.)

\section{Reflection Questions}

1. What are the potential risks to the participants of a possible capstone research project conducted at your field placement agency?

2. What are the potential benefits?

Sample informed consent letters can be found on the internet and at many university IRB websites. A fairly straightforward example that would be appropriate for many capstone research projects can be found on the Stanford University IRB website at https://web .stanford.edu/group/ncpi/unspecified/student_assess_toolkit/pdf/ sampleinformedconsent.pdf

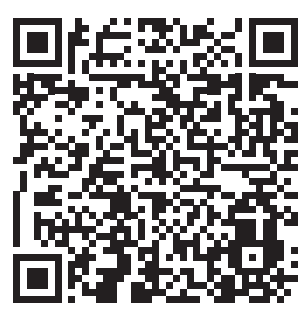

\section{Applied Research}

"Applied research" in social work typically focuses on finding solutions to organizational, community, and service-delivery problems. Applied research addresses practical issues encountered in the provision of social work services to clients and constituents. "Basic research," on the other hand, tends to focus on generalizations and theory development. Basic social science research seeks understanding of social phenomena. Thus, the major difference between applied and basic research is in their purposes. The purpose of applied research is to solve problems while the purpose of basic research is to generate new knowledge or add to the existing body of knowledge.

All types of research methods can be used to conduct applied research studies. It is the purpose and not the methods that makes it applied research. A common way to group research methods is quantitative versus qualitative approaches. Mixed-methods approaches combine both quantitative and qualitative data collection strategies. 
TABLE 1.1 TYPES OF APPLIED RESEARCH AND DATA TYPES

\begin{tabular}{|l|l|l|l|}
\hline TYPE & QUANTITATIVE & QUALITATIVE & MIXED METHOD \\
\hline Program evaluation & Yes & Yes & Yes \\
\hline Needs assessment & Yes & Yes & Yes \\
\hline Case studies & No & Yes & No \\
\hline $\begin{array}{l}\text { Qualitative descrip- } \\
\text { tive studies }\end{array}$ & No & Yes & No \\
\hline $\begin{array}{l}\text { Practice effective- } \\
\text { ness studies }\end{array}$ & Yes & No & No \\
\hline
\end{tabular}

Quantitative approaches involve collecting numerical data and using various statistical methods to analyze the collected data. A variety of data collection methods can be used with quantitative applied social work research. They include survey questionnaires, interview schedules, recording direct observations, and other approaches to collecting numerical data.

Qualitative approaches, on the other hand, are subjective and descriptive. Data collection is based on words or observations and the data analysis seeks to describe or interpret whatever is being researched. Instead of numbers, qualitative research collects information in the form of words. It relies on observation or participants' answers to open-ended questions (Melanson, 2020).

This book reviews five types of research that are often used in conducting applied social work research projects. The five types covered are (a) program evaluations, (b) organizational and community needs assessments, (c) case studies, (d) qualitative descriptive studies, and (e) practice effectiveness studies. Table 1.1 lists the five approaches and their data types (quantitative, qualitative, and/or mixed methods). This classification shows that program evaluations and needs assessment can be either quantitative or qualitative or employ both types of data. On the other hand, case studies and qualitative descriptive studies collect only qualitative data while practice effectiveness studies collect only quantitative type data.

\section{ACTION RESEARCH}

One of the best ways you can protect yourself from burnout in the field is by helping create positive change through action research (Schuyler et al., 2018). Imagine that your social work program's capstone project involves you assisting the neighborhood walk-in-clinic where you are interning in order to help evaluate its service-delivery system. Or, what if the Veteran's Administration field placement to which you are assigned is interested in assessing the effectiveness of its posttraumatic stress disorder (PTSD) treatment program? The actual problems, limitations, and challenges may not be known to the agency, so you will need to conduct a careful initial assessment.

You need to be aware that developing a thorough understanding of an agency's day-to-day operations, as well as discovering clients' experiences, needs, challenges, and 
responsibilities, will slowly emerge during the course of your project. Let us assume that you, your field supervisor, and the agency sponsoring your research have all agreed that it is vital to include client-based perspectives in your study, for it is not enough just to know whether the agency is operating effectively, it is imperative to know how well it works for the people it manages and serves (Lune \& Berg, 2017). This emphasis on the experiences, thoughts, opinions, and suggestions of those an agency or organization serves is a cornerstone of action research.

Action research is a developing process of inquiry that integrates theory and action to connect scientific knowledge with existing organizational knowledge. Action research also aims to address actual organizational problems with participation from the people who are part of the system being examined (Coghlan, 2011). It is a type of collaborative qualitative research that seeks action to improve organizational practice and then study the outcomes of the action that was taken. The primary purpose of action research is to improve or change what it seeks to study. When conducting this type of research, you stand with and alongside the participants of your study (Berg, 2007), engaging in collaborative and transparent relationships in order to create a space for open and honest dialogues (Reason \& Bradbury, 2008). Important themes in action research are the importance of practice effectiveness, client life experiences, the web of relationships, community building, and social change (Rutman et al., 2005).

According to Lune and Berg (2018), action research progresses through three basic phases. Those phases are looking, thinking, and taking action:

Looking-During this initial phase you assess the situation and create a general picture of what is going on. This involves collecting information and seeing who the stakeholders are and what their interests may be. When conducting your evaluation, you want to define and describe the problems or issues that need investigation, as well as the context in which they are found. You should also consider, and without judgment, what all the stakeholders have been doing. Stakeholders can contribute to this process by guiding you through your study's setting. Stakeholders can also inform you of previous efforts to address identified problems.

Thinking-This phase involves formulating interpretations and offering some explanation about issues or problems being faced. During your evaluation, you need to analyze the data you have collected, while simultaneously interpreting any problems as they currently exist. Next, you want to reflect on what your participants have been doing. You will accomplish this by having conversations with participants and reflecting on the issue or problem together. It is a good idea to take notes and/or record the conversations. These conversations will provide you with a means for further assessment of areas of success, as well as any deficiencies, issues, or problems that may confront the agency or any of its stakeholders. You will be responsible for interpreting the findings, but do not do it in isolation. Make sure others (e.g., your field supervisor or your seminar professor) assist you in this process. 
Action-This final phase of the process is what action research is all about, which is to resolve issues and problems by taking action toward improving the lives of your participants (stakeholders). Your evaluation report should offer considerations regarding which actions might result in the most positive changes in the agency and/or in the lives of its staff, interns, volunteers, and clients. The considerations you present should be framed within the lines of the value of any changes or interventions you propose, the appropriateness and potential effectiveness of your suggestions, and the probable outcomes of any action to be made toward the changes you propose. Working alongside an agency's stakeholders, you will work to formulate plans for solutions to problems that have been mutually identified. You then take the action plans you create back to the stakeholders so that you can further discussion and elaboration. Ultimately, and in line with the concept of participant empowerment, it will be the stakeholders themselves who will choose a new plan of action.

Although there are a number of action research paradigms that are antioppressive, deconstructionist, and revolutionary in nature (e.g., participatory action research, community-based action research, and antioppressive research), those approaches are beyond the scope and applicability of this chapter. If you are interested in knowing more about those approaches, read George and Syrja-McNally's (2015) work titled Social Enquiry

\section{Reflection Question}

Of the many areas of social work practice (e.g., child welfare, domestic violence, transitional housing, veterans' affairs, school social work), in what area would you like to see more Action Research take place? What are your reasons? and Action Research for Social Workers. The most useful ways for social work field interns to engage in action research, particularly in relation to their time-limited Research-Based Capstone Project, will be in the form of needs assessments and program evaluations.

\section{Competency Log: Capstone Project, Paper, and Presentation}

The capstone competency log (CCL) is designed to help you keep track of your activities and cognitive processes in carrying out your capstone project that are related to the social work professional competencies (CSWE, 2015). See Table 1.2. Your completed CCL will provide data that will document the professional competencies you demonstrated in completing your capstone research project, writing your final paper, and giving your oral presentation.

Each professional competency, as defined by the CSWE, is described in the CCL. The narrative descriptions of the competencies define them. The competencies are complex with multiple components and practice behaviors. The CSWE identified five competency dimensions-knowledge, values, skills, affective reactions, and cognitive processes. The CCL covers the knowledge, skills, and cognitive process dimensions. These are the competency dimensions that are best captured by an applied research project. The practice behaviors listed after the competency descriptions are examples of the skill dimension for that competency. The number of practice behaviors for each competency has been 
expanded beyond the examples listed in the CSWE 2015 EPAS. The practice behaviors were expanded in an attempt to capture more of the content items identified in the competency descriptions. Some of the competencies and many of the practice behaviors will not be relevant to your capstone project.

We recommend that as you research your study topic, design and implement your project, and prepare your capstone paper and presentation, you make ongoing entries in your CCL. Keep your CCL current and up to date. Review each competency each week and reflect upon your project activities related to the competencies. Date and describe the activity, reflect upon how it relates to the competency, and then summarize your

TABLE 1.2 CAPSTONE COMPETENCY LOG

\begin{tabular}{|c|c|c|c|}
\hline ACTIVITY & KNOWLEDGE & SKILLS & $\begin{array}{l}\text { COGNITIVE } \\
\text { PROCESS }\end{array}$ \\
\hline $\begin{array}{l}\text { Date and describe } \\
\text { the capstone } \\
\text { research, paper, or } \\
\text { presentation activ- } \\
\text { ity related to the } \\
\text { ethical and profes- } \\
\text { sional behavioral } \\
\text { competency. }\end{array}$ & $\begin{array}{l}\text { Summarize your } \\
\text { knowledge of } \\
\text { ethical and pro- } \\
\text { fessional behavior } \\
\text { and describe how } \\
\text { you demonstrate } \\
\text { that knowledge in } \\
\text { the activity. }\end{array}$ & $\begin{array}{l}\text { Identify the ethical } \\
\text { and professional } \\
\text { practice behavior(s) } \\
\text { you used with the } \\
\text { activity and reflect } \\
\text { upon your effective- } \\
\text { ness in implement- } \\
\text { ing the skill. }\end{array}$ & $\begin{array}{l}\text { Describe your cog- } \\
\text { nitive processes } \\
\text { and how your crit- } \\
\text { ical thinking influ- } \\
\text { enced your project } \\
\text { decisions. }\end{array}$ \\
\hline $\begin{array}{l}\text { Date: } 9 / 12 / 21 \text { : } \\
\text { Reviewed the NASW } \\
\text { Code of Ethics } \\
\text { ethical standards } \\
\text { on Evaluation and } \\
\text { Research (5.02). }\end{array}$ & $\begin{array}{l}\text { After reviewing eth- } \\
\text { ical standards } 5.02 \\
\text { I identified seven } \\
\text { standards that had } \\
\text { particular relevance } \\
\text { for the initial stages } \\
\text { of my research proj- } \\
\text { ect. They were: (d) } \\
\text { consider possible } \\
\text { consequences, (e) } \\
\text { voluntary and written } \\
\text { informed consent, (i) } \\
\text { right to withdraw, (j) } \\
\text { access to supportive } \\
\text { services, (k) protec- } \\
\text { tion from harm, (m) } \\
\text { confidentiality, and } \\
\text { (p) avoiding con- } \\
\text { flict of interest and } \\
\text { dual relationships. } \\
\text { I understand and } \\
\text { am knowledgeable } \\
\text { about the meaning } \\
\text { of these ethical } \\
\text { standards. }\end{array}$ & $\begin{array}{l}\text { The competency } \\
\text { practice behaviors } \\
\text { related to this activ- } \\
\text { ity are (a) adhere } \\
\text { to the core social } \\
\text { work values and } \\
\text { NASW ethical prin- } \\
\text { ciples, and (b) follow } \\
\text { ethical standards } \\
\text { in conducting } \\
\text { research studies. } \\
\text { At this point, I have } \\
\text { identified the prac- } \\
\text { tice behaviors but } \\
\text { it is too early in my } \\
\text { project to evaluate } \\
\text { my effectiveness in } \\
\text { implementing these } \\
\text { skills. }\end{array}$ & $\begin{array}{l}\text { In reviewing the } \\
\text { relevant ethical stan- } \\
\text { dards, I concluded } \\
\text { that (e) voluntary } \\
\text { and written informed } \\
\text { consent, (k) right to } \\
\text { withdraw, and (m) } \\
\text { ensuring confidenti- } \\
\text { ality will be handled } \\
\text { with the informed } \\
\text { consent form. } \\
\text { However, identifying } \\
\text { (d) possible conse- } \\
\text { quences, (j) access } \\
\text { to support services, } \\
\text { (k) protection from } \\
\text { harm, and (p) avoid } \\
\text { conflict of interest } \\
\text { and dual relation- } \\
\text { ships will require } \\
\text { additional research } \\
\text { and reflection to } \\
\text { be comprehen- } \\
\text { sively addressed in } \\
\text { my research. }\end{array}$ \\
\hline
\end{tabular}


TABLE 1.2 CAPSTONE COMPETENCY LOG (continued)

\begin{tabular}{|c|c|c|c|}
\hline ACTIVITY & KNOWLEDGE & SKILLS & $\begin{array}{l}\text { COGNITIVE } \\
\text { PROCESS }\end{array}$ \\
\hline $\begin{array}{l}\text { Date: } 9 / 14 / 21 \text { : Iden- } \\
\text { tified the procedures } \\
\text { I will need to employ } \\
\text { to avoid the conflict } \\
\text { of interest ethical } \\
\text { standard with my } \\
\text { study participants. }\end{array}$ & $\begin{array}{l}\text { Since I cofacilitate } \\
\text { the Peer Support } \\
\text { Group, my person- } \\
\text { ally asking the partic- } \\
\text { ipants to fill out the } \\
\text { study questionnaires } \\
\text { is a potential conflict } \\
\text { of interest. I would } \\
\text { be asking the par- } \\
\text { ticipants to evaluate } \\
\text { a program that I } \\
\text { run. This could be } \\
\text { viewed as a conflict } \\
\text { of interest. }\end{array}$ & $\begin{array}{l}\text { The applicable } \\
\text { practice behavior is: } \\
\text { Follow ethical stan- } \\
\text { dards in conducting } \\
\text { research studies. } \\
\text { I believe that my } \\
\text { plan to avoid conflict } \\
\text { of interest demon- } \\
\text { strates my compe- } \\
\text { tency in applying the } \\
\text { practice behavior } \\
\text { to my capstone } \\
\text { research project. }\end{array}$ & $\begin{array}{l}\text { To help minimize the } \\
\text { potential for conflict } \\
\text { of interest, I decided } \\
\text { to: } \\
\text { (1) make sure the } \\
\text { informed consent } \\
\text { form clearly states } \\
\text { that participation } \\
\text { is voluntary, that } \\
\text { participation has no } \\
\text { bearing on receiving } \\
\text { program services, } \\
\text { participation is com- } \\
\text { pletely confidential, } \\
\text { and that people can } \\
\text { withdraw without } \\
\text { penalty at any time; } \\
\text { (2) I have decided to } \\
\text { have another intern } \\
\text { introduce the study, } \\
\text { obtain informed } \\
\text { consent, distribute } \\
\text { and collect the study } \\
\text { questionnaire. I will } \\
\text { be absent from the } \\
\text { room during this } \\
\text { process. }\end{array}$ \\
\hline \multicolumn{4}{|l|}{ Date: } \\
\hline \multicolumn{4}{|l|}{ Date: } \\
\hline $\begin{array}{l}\text { Summary: Describe } \\
\text { your ethical and } \\
\text { professional behav- } \\
\text { ioral competencies } \\
\text { for the knowledge, } \\
\text { skills, and cognitive } \\
\text { process dimensions } \\
\text { in completing your } \\
\text { capstone research } \\
\text { project, paper, and } \\
\text { presentation. Iden- } \\
\text { tify your strengths } \\
\text { and your challenges } \\
\text { for each dimension. }\end{array}$ & Knowledge: & Skills: & Cognitive Processes: \\
\hline
\end{tabular}


competency knowledge, skills, and cognitive processes related to the activity. Box 1.1 is a sample CCL for Competency \#1. An electronic copy of the CCL can be found online in the Student Toolbox provided by Springer Publishing Company at www.springerpub .com/capstone. The online CCL covers all nine of the professional social work competencies.

\section{BOX 1.1}

\section{SAMPLE COMPETENCY LOG}

Student Name: Jessica Jones

Course Number and Name: SW621—Capstone Research

Brief Description of Capstone Project: A quantitative evaluation of the Teens Together Program that serves homeless LGBTQ teenagers. The evaluation focuses on the participants' overall satisfaction with the program and with the Peers Together support group component. In addition to participant satisfaction, the evaluation will assess the impact the Peers Together program has on the participants' self-esteem, perceived social support, and family relationships.

\section{Competency 1: Demonstrate Ethical and Professional Behavior}

Social workers understand the value base of the profession and its ethical standards, as well as relevant laws and regulations that may impact practice at the micro, mezzo, and macro levels. Social workers understand frameworks of ethical decision-making and how to apply principles of critical thinking to those frameworks in practice, research, and policy arenas. Social workers recognize personal values and the distinction between personal and professional values. They also understand how their personal experiences and affective reactions influence their professional judgment and behavior. Social workers understand the profession's history, its mission, and the roles and responsibilities of the profession. Social workers also understand the role of other professions when engaged in interprofessional teams. Social workers recognize the importance of lifelong learning and are committed to continually updating their skills to ensure they are relevant and effective. Social workers also understand emerging forms of technology and the ethical use of technology in social work practice.

- Adhere to the core social work values and NASW ethical principles.

- Make ethical decisions by applying the ethical standards of the NASW Code of Ethics, relevant laws and regulations.

- Use ethical decision-making models to resolve ethical dilemmas.

- Follow ethical standards in conducting research studies.

- Use refection and self-regulation to manage personal values and maintain professionalism.

- Use reflection to understand how affective reactions influence practice decisions and professional judgment.

- Demonstrate professional behavior and appearance in oral communication.

- Demonstrate professional behavior in written, and electronic communication.

- Demonstrate understanding of the roles and responsibilities of all disciplines when engaged in interprofessional teams.

- Use technology ethically and appropriately to facilitate practice outcomes.

- Participate in professional development and trainings.

- Use supervision and consultation to guide professional judgment and behavior. 


\section{PRACTICE ACTIVITIES}

1. Create an informed consent form for a hypothetical applied research capstone project that you think could be conducted at your field placement agency. Make sure your consent form covers all of the information listed earlier and that it has a reading level no higher than 10.0. Its reading level can be calculated in Microsoft Word under the spell check function. It calculates the Flesch-Kincaid Grade level of a whole document or any select portion of a document.

2. Identify all the potential ethical issues associated with your hypothetical research project and list the possible ways each ethical issue could be addressed.

\section{TECHNOLOGY EXERCISES}

1. Access your college or university IRB website and review the IRB policies and application procedures to determine if your hypothetical student research project requires an IRB application. As a nonstudent project, would your hypothetical research study need a full board, expedited, or exempt review?

2. Research the internet to identify a free IRB certification-training course. Complete the online course.

\section{REFERENCES}

Berg, B. L. (2007). Qualitative research methods for social sciences (6th ed.). Pearson Education. Boston University. (2020). Determination of research and research involving human subjects. http://www.bu.edu/researchsupport/compliance/human-subjects/determining-if-irb -approval-is-needed

Boston University. (n.d.). Tips for creating a consent document. http://www.bu.edu/ researchsupport/compliance/human-subjects/tips-for-creating-a-consent-document

Coghlan, D. (2011). Action research: Exploring perspectives on a philosophy of practical knowing. Academy of Management Annals, 5(1), 53-87. https://doi.org/10.1080/19416520 .2011 .571520

Collins, E., \& Daly, E. (2011). Decision making and social work in Scotland: The role of evidence and practice wisdom. Institute for Research and Innovation in Social Sciences. https://www .iriss.org.uk/resources/reports/decision-making-and-social-work-scotland

Congress, E., \& McAuliffe, D. (2006). Social work ethics: Professional codes in Australia and the United States. International Social Work, 49, 151-164. https://doi .org/10.1177/0020872806061211

Council on Social Work Education. (2015). Educational policy and accreditation standards. https://www.cswe.org/getattachment/Accreditation/Standards-and-Policies/2015-EPAS/ 2015EPASandGlossary.pdf.aspx

Department of Health and Human Services. (2016). 45 CFR subtitle A (10-1-16 edition). https:// www.govinfo.gov/content/pkg/CFR-2016-title45-vol1/pdf/CFR-2016-title45-vol1-part46.pdf

DuBois, B., \& Miley, K. K. (2014). Social work: An empowering profession (8th ed.). Pearson.

George, P., \& Syrja-McNally, D. (2015). Social enquiry and action research for social work. In J. D. Wright (Ed.), International encyclopedia of the social \& behavioral sciences (2nd ed., pp. 269-274). Elsevier. 
Gumpert, J., \& Black, P. (2006). Ethical issues in group work: What are they? How are they managed? Social Work with Groups, 29(4), 61-74. https://doi.org/10.1300/J009v29n04_05

Heron, G. (2006). Critical thinking in social care and social work: Searching student assignments for the evidence. Social Work Education, 25, 209-224. https://doi.org/10.1080/ 02615470600564965

McKnight, S. E. (2013). Mental health learning needs assessment: Competency-based instrument for best practice. Issues in Mental Health Nursing, 34, 459-471. https://doi.org/ $10.3109 / 01612840.2012 .758205$

Lune, H., \& Berg, B. (2017). Qualitaive research methods for the social sciences (9th ed.). Pearson.

Melanson, G. (2020). What are the different kinds of research? Wisegeek. https://www.wisegeek .com/what-are-the-different-types-of-research.htm\#

National Association of Social Workers. (2017). Code of ethics. https://www.socialworkers.org/ about/ethics/code-of-ethics

Poulin,J., \&Matis, S.(2015). Socialwork competenciesand multidimensionalassessment.Journal of Baccalaureate Social Work, 20, 117-135. https://doi.org/10.18084/1084-7219.20.1.117

Poulin, J., \& Matis, S. (2020). Social work practice: A competency-based approach. Springer Publishing Company.

Poulin, J., Matis, S., \& Witt, H. (2019). The social work field placement: A competency-based approach. Springer Publishing Company.

Reamer, F. G. (2013). Social work values and ethics (4th ed.). Columbia University Press.

Reason, P., \& Bradbury, H. (2008). Introduction to grounding. In W. K. Caroll (Ed.), SAGE handbook of action research: Participative inquiry and practice (2nd ed., pp. 11-14). SAGE Publications.

Rubaltelli, E., \& Slovic, P. (2008). Affective reaction and context-dependent processing of negations. Judgement and Decision Making, 3, 607-618. http://journal.sjdm.org

Rutman, D., Hubberstey, C., Barlow, A., \& Brown, L. (2005). Supporting young people’s transitions from care: Reflections on doing participatory action research with youth from care. In L. Brown \& S. Strega (Eds.), Research as resistance: Critical, indigenous \& anti-oppressive approaches (pp. 153-180). Canadian Scholars' Press/Women's Press.

Schuyler, K. G., Taylor, M. O., \& Wolberger, O. M. (2018). Bringing mindfulness and joy to work: Action research on organizational change. In J. Neal (Ed.), Handbook of personal and organizational transformation (pp. 1193-1217). Springer.

The Glossary of Educational Reform. (2013). Learning pathway. https://www.edglossary.org/ learning-pathway

The Glossary of Educational Reform. (2016). Capstone project. https://www.edglossary.org/ capstone-project

The National Commission for the Protection of Human Subjects of Biomedical and Behavioral Research. (1979). The Belmont Report: Ethical principles and guidelines for the protection of human subjects of research. https://www.hhs.gov/ohrp/regulations-and-policy/belmont -report/index.html

U.S. Food and Drug Administration. (2019, April). Code of Federal Regulations, Title 21. https:// www.accessdata.fda.gov/scripts/cdrh/cfdocs/cfCFR/CFRSearch.cfm?CFRPart $=56 \&$ showFR $=1 \&$ subpartNode $=21: 1 \cdot 0.1 \cdot 1.22 .3$ 